\title{
A key continental archive for the last 2 Ma of climatic history of the central Mediterranean region: A pilot drilling in the Fucino Basin, central Italy
}

\author{
B. Giaccio ${ }^{1}$, E. Regattieri ${ }^{1}$, G. Zanchetta ${ }^{2}$, B. Wagner ${ }^{3}$, P. Galli ${ }^{1,4}$, G. Mannella ${ }^{2}$, E. Niespolo ${ }^{5}$,

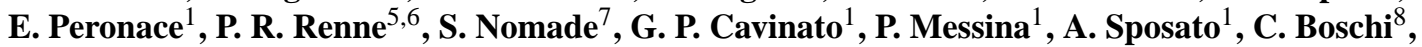 \\ F. Florindo ${ }^{9}$, F. Marra $^{9}$, and L. Sadori ${ }^{10}$ \\ ${ }^{1}$ Istituto di Geologia Ambientale e Geoingegneria, CNR, Rome, Italy \\ ${ }^{2}$ Dipartimento di Scienze della Terra, UniPI, Pisa, Italy \\ ${ }^{3}$ Institute of Geology and Mineralogy, University of Cologne, Cologne, Germany \\ ${ }^{4}$ Dipartimento di Protezione Civile Nazionale, Rome, Italy \\ ${ }^{5}$ Department of Earth and Planetary Science, University of California, Berkeley, USA \\ ${ }^{6}$ Berkeley Geochronology Center, Berkeley, USA \\ ${ }^{7}$ Laboratoire des Sciences du Climat et de l'Environnement (CEA-CNRS-UVSQ), Gif-Sur-Yvette, France \\ ${ }^{8}$ Istituto di Geoscienze e Georisorse, CNR, Pisa, Italy \\ ${ }^{9}$ Istituto Nazionale di Geofisica Vulcanologia, Rome, Italy \\ ${ }^{10}$ Dipartimento di Biologia Ambientale, University of Rome "La Sapienza”, Rome, Italy \\ Correspondence to: B. Giaccio (biagio.giaccio@cnr.it)
}

Received: 9 September 2015 - Revised: 10 November 2015 - Accepted: 15 November 2015 - Published: 17 December 2015

\begin{abstract}
An $82 \mathrm{~m}$ long sedimentary succession was retrieved from the Fucino Basin, the largest intermountain tectonic depression of the central Apennines. The basin hosts a succession of fine-grained lacustrine sediments (ca. $900 \mathrm{~m}$-thick) possibly continuously spanning the last $2 \mathrm{Ma}$. A preliminary tephrostratigraphy study allows us to ascribe the drilled $82 \mathrm{~m}$ long record to the last $180 \mathrm{ka}$. Multi-proxy geochemical analyses (XRF scanning, total organic/inorganic carbon, nitrogen and sulfur, oxygen isotopes) reveal noticeable variations, which are interpreted as paleohydrological and paleoenvironmental expressions related to classical glacial-interglacial cycles from the marine isotope stage (MIS) 6 to present day. In light of the preliminary results, the Fucino sedimentary succession is likely to provide a long, continuous, sensitive, and independently dated paleoclimatic archive of the central Mediterranean area.
\end{abstract}

Understanding the spatio-temporal variability, the magnitude, and the different expressions of Quaternary orbital and millennial-scale paleoclimatic changes across regions is a frontier challenge of modern paleoclimatology (e.g. EPICA community members, 2006). Addressing this issue requires the acquisition of regionally representative high-resolution and well-dated records of climatic variability.

In this framework, the Fucino paleolake in central Italy (Fig. 1a) should add a nodal point in the western, currently vacant area of a network of long terrestrial Mediterranean records (including e.g. the Dead Sea (Neugebauer et al., 2014), Lake Van (Litt and Anselmetti, 2014), Lake Ohrid (Wagner et al., 2009), and the Tenaghi Philippon (Pross et al., 2015)). Indeed, among the central Italy intermountain tectonic depressions, it is probably one of the oldest and the only one that hosts a continuous, lacustrine succession since the late Plio-Quaternary (Fig. 1b). The site is also ideal because of its proximity to Quaternary peri-Tyrrhenian volcanic centres (Fig. 2) that on occasion deposited tephras in the basin that serve today as important chronological marker beds (e.g. Giaccio et al., 2012, 2015; Regattieri et al., 2015). This is a crucial requirement for comparing intra- and inter-regional 


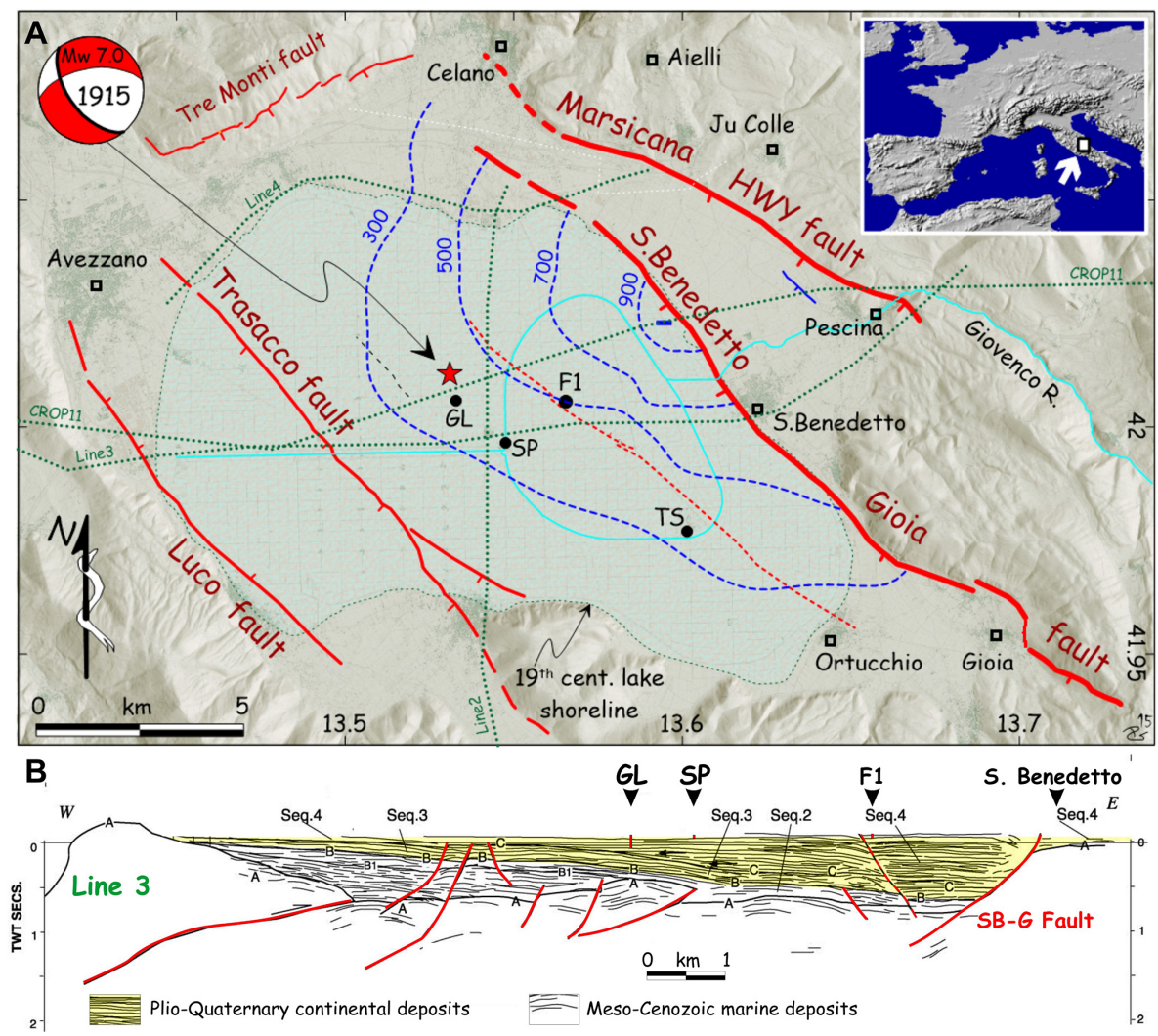

Figure 1. Reference map of the Fucino Plain with a representative seismic line. (a) Shaded relief of the Fucino Plain showing the location of the GeoLazio (GL), Telespazio (TS), Strada Provinciale 20 (SP) and Fucino 1 and 3 (F1-3; this study) boreholes. Dashed blue lines are the isochrones (in ms) of the Plio-Quaternary basin infilling with respect to the Quaternary master faults (red bold lines) responsible for the asymmetrical (half-graben) basin geometry. Dotted green lines are the traces of the available seismic lines. (b) Seismic line 3 (see trace in panel a) showing the internal architecture of the Plio-Quaternary continental deposits of the Fucino Basin along a W-E-oriented profile. The projected location of the GL, SP, and F1-3 boreholes is also shown. A, B, C: main unconformities; Seq. 2: Messinian foredeep sediments; Seq. 3: Pliocene fluvial and alluvial deposits; Seq. 4: Quaternary lacustrine and fluvial deposits. The figure and the information were compiled with some modifications from Cavinato et al. (2002), Galli et al. (2012), and Patacca et al. (2008).

paleoclimatic records, based on different dating methods, for evaluating the temporal relationship between them and with respect to the main climatic forcing (e.g. orbital).

With this purpose, an $82 \mathrm{~m}$ long core was recovered from the central eastern Fucino Basin (F1-3 in Fig. 1) in June 2015. The major goals of this drilling were to (i) collect a continuous record back to MIS (marine isotope stage) 6 , (ii) assess the quality of the lacustrine sedimentary succession, (ii) explore the sensitivity of different paleoclimatic proxies, and (iii) document the presence of widespread tephras useful for regional to extra-regional correlation and their suitability for ${ }^{40} \mathrm{Ar} /{ }^{39} \mathrm{Ar}$ dating.

\section{Geological setting and general background}

The Fucino Basin (Fig. 1) is one of the largest intermountain depressions formed during the Plio-Quaternary extensional phase along the Apennine Chain (e.g. D'Agostino et al., 2001) within the earlier fold-and-thrust-belt system (e.g.
Patacca and Scandone, 2007). Its opening was mainly driven by a major $110-130^{\circ} \mathrm{N}$ trending fault system (Galadini and Galli, 2000; Fig. 1a), which led to the formation of a typical half graben with up to $\sim 900 \mathrm{~m}$ of thick Quaternary deposits in the hanging wall of the master faults (Cavinato et al., 2002; Fig. 1b). Prior to the drainage, undertaken first by Romans in 1st century AD and then at the end of the 19th century (e.g. Galadini and Galli, 2001), the Fucino Basin hosted the largest lake $\left(\sim 150 \mathrm{~km}^{2}, 20 \mathrm{~m}\right.$ maximum water depth) of peninsular Italy.

In the past decades, several cores were drilled in the Fucino Basin for scientific and geotechnical purposes (Fig. 1). A preliminary palynological study of the $200 \mathrm{~m}$ long GeoLazio core (GL in Fig. 1) led to the conclusion that the upper $65 \mathrm{~m}$ of the succession would span the last $130 \mathrm{ka}$ (Follieri et al., 1986). However, the dating of a thick tephra layer at $\sim 101 \mathrm{~m}$ depth yielded an age of $540 \pm 9 \mathrm{ka}$ (Follieri et al., 1991), hardly compatible with this chronological framework. Later, Narcisi (1994) analysed two foiditic tephra occurring 


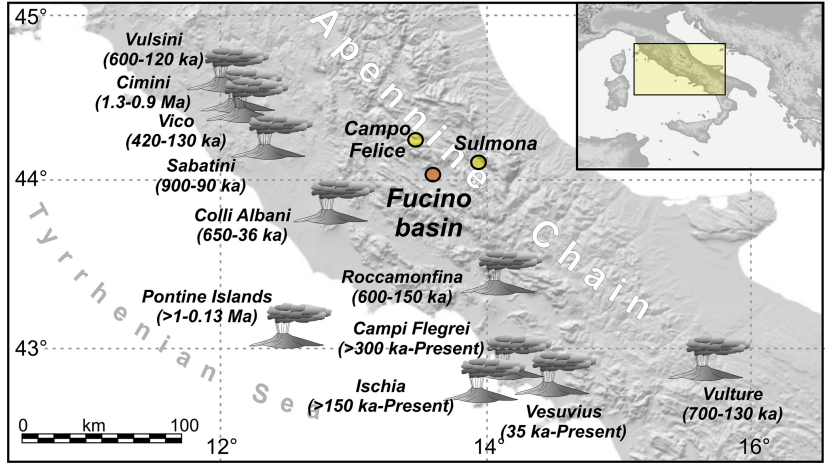

Figure 2. Location of the Fucino Basin with respect to the main volcanic districts of central and southern Italy (age in brackets represent the interval of volcanic activity). It is in a good range of distance with respect to the Quaternary tephra sources and in a favourable position with respect to the prevailing eastward direction of the stratospheric winds and hence for tephra dispersion. The locations of Sulmona and Campo Felice are also shown.

in the GeoLazio and Telespazio cores (TS in Fig. 1), at $~ 12-$ $14 \mathrm{~m}$ depth, which, on the basis of their peculiar glass major element composition, were attributed to the eruptive units Albano 5-7 (Giaccio et al., 2007), from a cluster of Colli Albani eruptions dated between 40 and $36 \mathrm{ka}$ (Giaccio et al., 2009). Finally, the tephrostratigraphic study of a $30 \mathrm{~m}$ deep borehole (SP in Fig. 1a) drilled close to the GeoLazio site, and in a comparable range of the isochrones of the Quaternary infill (Fig. 1a), allowed for the recognition of some relevant tephra markers spanning between ca. 18 and ca. $160 \mathrm{ka} \mathrm{(Au-}$ thors' unpublished data; Fig. 3). All of these chronological constraints lead us to a reinterpretation of the chronology of the GeoLazio pollen record, spanning the MIS 1-9 interval, suggesting that the Fucino succession extends continuously at least back to $\sim 540 \mathrm{ka}$ (Fig. 3).

\section{Material and methods}

\subsection{Drilling site selection and procedure}

The drilling site was selected using an evaluation of sedimentation rate obtained from the new interpretation of the GeoLazio pollen profile (Fig. 3) and the general sedimentarytectonic architecture of the basin (Fig. 1). With the aim to recover a record spanning back into MIS 6, we selected an area located some kilometres eastward from the GeoLazio and SP core sites, i.e. toward the depocentre where the isochrones are deeper (Fig. 1). Therefore, this site provided us the opportunity of recovering a succession more expanded than the GeoLazio core.

At the selected site $\left(42.00^{\circ} \mathrm{N}, 13.56^{\circ} \mathrm{E}\right)$, two parallel cores were recovered. The first hole (F1) was drilled down to a field depth of $75 \mathrm{~m}$ and the second hole (F3) down to $56.25 \mathrm{~m}$. The length of the single recovered core section was $1.5 \mathrm{~m}$, with an

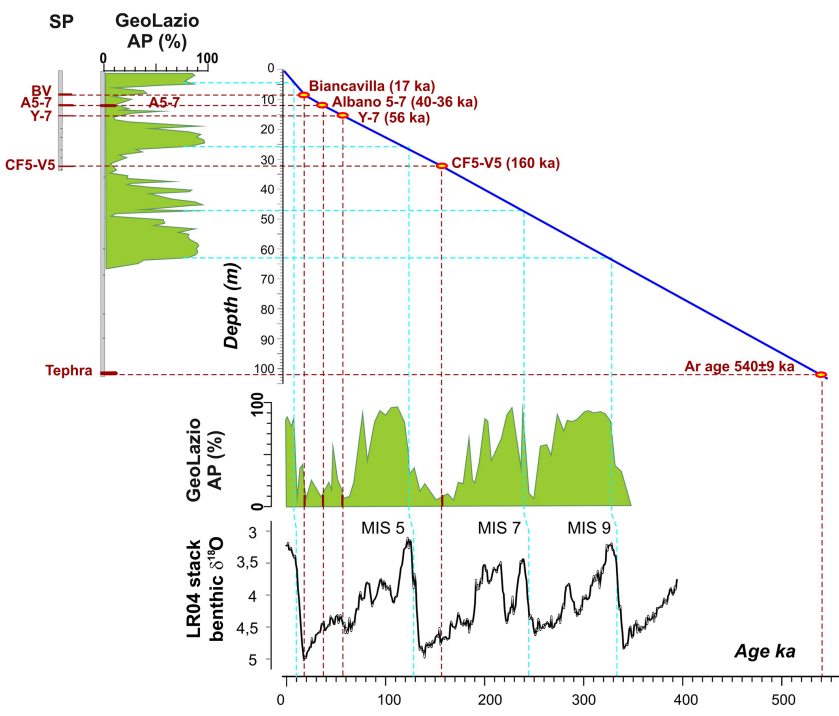

Figure 3. Revised depth-age curve for the GeoLazio arboreal pollen (AP) profile (Follieri et al., 1986) based on the recognition of marker tephra layers in core SP (Fig. 1) and on the dating of the layer at $\sim 101 \mathrm{~m}$ of depth in core GeoLazio (Follieri et al., 1991). After revision, the resulting AP curve shows a variability, which correlates quite well the benthic $\delta^{18} \mathrm{O}$ stack (Lisiecki and Raymo, 2005) from MIS 9 to today.

overlap of $75 \mathrm{~cm}$ between the two holes, in order to obtain a complete sedimentary succession for the upper part of the sequence. Samples from core catchers were taken directly in the field, whereas the rest of the cores were stored in a dark and cool place for further analyses.

\subsection{Laboratory work}

\subsubsection{Lithological analyses and XRF scanning}

Core opening and core description was carried out at the laboratory of the University of Cologne, Germany. Immediately after core opening, a surface scan of each core section was carried out with a line scan camera from an Itrax core scanner (Cox, Sweden). Further analyses included XRF (X-ray fluorescence) scanning carried out with a chromium $(\mathrm{Cr}) \mathrm{X}$ ray source at $30 \mathrm{kV}$ and $55 \mathrm{~mA}$ at $2.5 \mathrm{~mm}$ resolution and $10 \mathrm{~s}$ integration time.

\subsubsection{Geochemical analyses on core catcher material}

Total carbon (TC), total inorganic carbon (TIC), total nitrogen (TN), total sulfur (TS), and stable oxygen isotope compositions were carried out on discrete samples from the top of each core catcher. Samples were dried in an oven at $50^{\circ} \mathrm{C}$. After disaggregation and sieving, the fraction below $100 \mu \mathrm{m}$ was powdered and homogenized for geochemical analyses.

Stable isotope analyses were performed on samples with $>20 \%$ carbonate content using a GasBench II (Thermo Scientific) coupled to a Delta XP IRMS (Finnigan) at the In- 


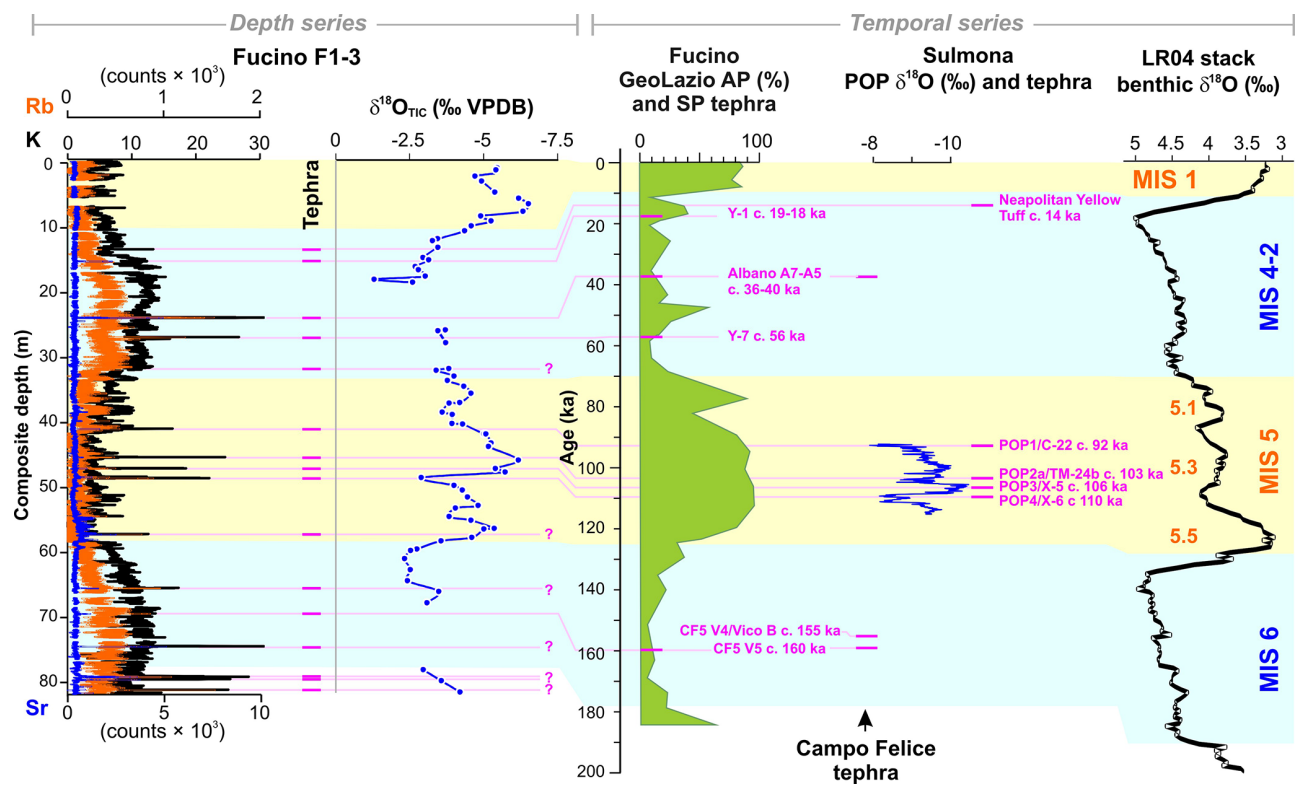

Figure 4. Provisional tephrochronological framework of the Fucino F1-3 composite stratigraphy. The provisional correlation of some of the F1-F3 tephras - which are also depicted by peaks in $\mathrm{K}, \mathrm{Rb}$, and $\mathrm{Sr}$ - has been tentatively established on their stratigraphic order and lithological features compared to the tephra successions from the local cores of Fucino SP and the chronologically recalibrated GeoLazio and cores from the surrounding basins of Campo Felice (Giraudi and Giaccio, 2015) and Sulmona (Giaccio et al., 2012; Regattieri et al., 2015) (Fig. 2).

stitute of Geosciences and Earth Resources of the Italian National Research Council (IGG-CNR) of Pisa (Italy). Carbonate samples of $\sim 0.15 \mathrm{mg}$ of total $\mathrm{CaCO}_{3}$ were dissolved in $\mathrm{H}_{3} \mathrm{PO}_{4}(100 \%)$ for $1 \mathrm{~h}$ at $70^{\circ} \mathrm{C}$. All the results are reported relative to the V-PDB (Vienna Pee Dee Belemnite) international standard and corrected using the international standards NBS-18 (National Bureau of Standards) and a set of three internal standards. The analytical uncertainties for $\delta^{18} \mathrm{O}$ and $\delta^{13} \mathrm{C}$ are 0.17 and $0.15 \%$ respectively. TN and TS were determined with a vario Micro cube combustion CNS elemental analyser (Elementar, Germany) after combustion at $1150^{\circ} \mathrm{C}$ at the University of Cologne, Germany. TC and TIC were measured with a DIMATOC 200 (DIMATEC, Germany) at the University of Cologne, Germany. TOC was calculated by subtracting TIC from TC.

\section{First results and preliminary discussion}

Both cores are composed of grey lacustrine calcareous marl, with a variable proportion of clay. A preliminary $82 \mathrm{~m}$ long composite succession is based on visual correlation after core opening and using the line scan images from the Itrax core scanner (Cox Analytical, Sweden) and the Corewall software package (Corelyzer 2.0.1). Core sections that looked disturbed from the coring process were not included in the core composite. Although, theoretically, the drilling depths should have avoided gaps between the individual runs in each hole, overlapping sequences in the lower part of the F3 hole indicated gaps of around $20 \mathrm{~cm}$ between the individual runs of the F1 hole due to core expansion after recovery. We therefore assumed $20 \mathrm{~cm}$ gaps between the $\mathrm{F} 1$ sequences, where there were no overlapping F3 sequences; i.e. for the depths $>\sim 55 \mathrm{~m}$. Based on the core composite stratigraphy, $\mathrm{Ca}, \mathrm{K}$, $\mathrm{Ti}, \mathrm{Rb}$, and $\mathrm{Sr}$ data from XRF scanning were compiled to produce an overview profile.

At least 16 centimetric to decimetric thick and relatively coarse-grained tephra layers were identified along the composite core, several of which are also clearly marked by prominent spikes in $\mathrm{K}, \mathrm{Rb}$, and $\mathrm{Sr}$ (Fig. 4). A provisional correlation of some of the tephras has been tentatively established based on their stratigraphic order and lithological features (e.g. overall tephra colour, thickness, grain size, assortment of the mineral and lithic components, and colour and shape of the juvenile clasts) compared to the local tephra successions from the Fucino core SP and the chronologically recalibrated GeoLazio core (Fig. 3) and cores from the surrounding basins of Campo Felice (Giraudi and Giaccio, 2015) and Sulmona (Giaccio et al., 2012; Regattieri et al., 2015) (Figs. 3, 4). Although the lack of robust geochemical data renders it premature to propose an age model based on tephrochronology alone, general tephrostratigraphic consistency allows us to ascribe the investigated successions to the MIS 6-1 period. The resulting sedimentation rate would range between $\sim 0.3$ and $0.6 \mathrm{~mm} \mathrm{a}^{-1}$, with a mean of $\sim 0.45 \mathrm{~mm} \mathrm{a}^{-1}$, which is substantially higher than that of the GeoLazio/SP succession $\left(\sim 0.2 \mathrm{~mm} \mathrm{a}^{-1}\right.$; Fig. 3$)$. 


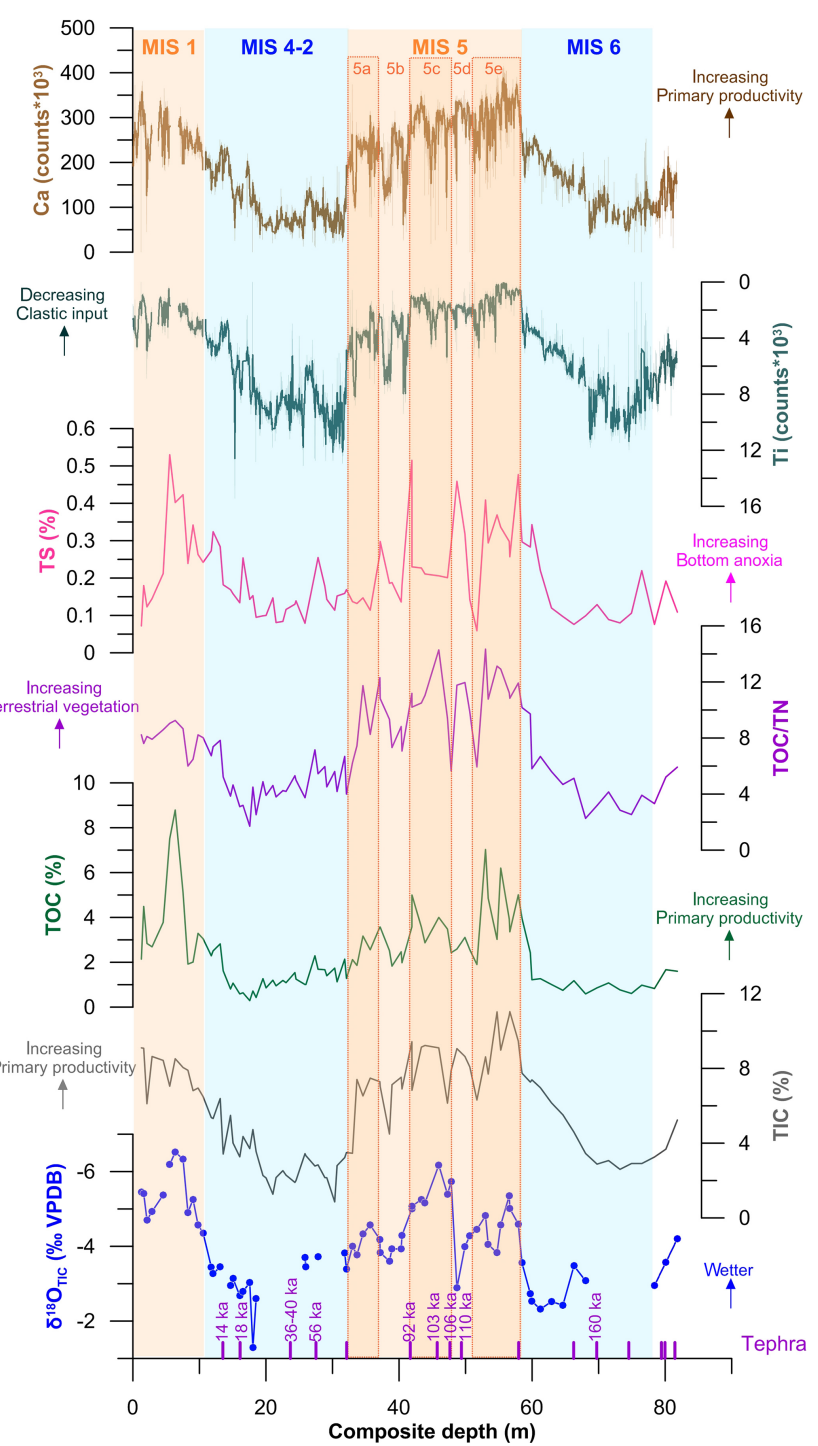

Figure 5. Proxy series plotted on preliminary composited depth. From bottom, provisional age control points based on the supposed recognition of the tephra layers as shown in Fig. $4: \delta^{18} \mathrm{O}_{\mathrm{TIC}}$, total inorganic carbon (TIC \%), total organic carbon (TOC \%), TOC / TN ratio, total sulfur (TS \%) (all from the same core catcher samples), and $\mathrm{Ti}$ and $\mathrm{Ca}$ from XRF scanning; thick lines are $20 \mathrm{pt}$ running averages, note that the Ti scale is reversed. Blue/pink shadowing indicates marine isotope stages (MIS) following the correlation proposed in Fig. 4. The provisional sub-stage subdivision of the MIS 5 is also shown.

Geochemical and biogeochemical analyses from core catcher material show significant variability, with major trends consistent between the different proxies and with XRF data for $\mathrm{Ca}$ and $\mathrm{Ti}$ (Fig. 5). There is a strong $(r=0.95)$ negative correlation between $\mathrm{Ca}$ and $\mathrm{Ti}$. Due to this strong anticorrelation and to the fact that $\mathrm{Ca}$ and TIC depth series show nearly identical patterns of variation, we assume that both proxies are mainly related by authigenic (i.e. biomediated) precipitation of calcite. The amount of calcite in the sediments depends on lake primary productivity, temperature, the input of $\mathrm{Ca}$ from the catchment (e.g. Gierlowsky-Kordesh, 2010; Vogel et al., 2010), and the preservation of calcite as a function of organic matter (OM) decomposition and bacterial $\mathrm{CO}_{2}$ release in the bottom waters (e.g. Müller et al., 2006). Also, TOC is mainly a function of changes in organic production in the lake and of changes in catchment vegetation (Leng et al., 2013), and, along with TIC, it tends to be higher during warmer and wetter periods (i.e. interglacials/interstadials). During these periods, calcite (TIC $\times 8.33$ ) and organic matter (TOC $\times \sim 2.5$ ) derived from TIC and TOC may form up to $>90 \%$ of the total sediments (Fig. 5). This suggests the negligible contribution of clastic, minerogenic input from catchment erosion and is consistent with the low Ti concentration (e.g. Vogel et al., 2010). $\delta^{18} \mathrm{O}_{\mathrm{TIC}}$ of most Mediterranean lakes is instead considered a proxy for the balance of precipitation vs. lake evaporation (e.g. Roberts et al., 2008), with higher or lower values related to decreasing or increasing moisture conditions, respectively.

The TOC / TN ratio is often related to the source of the $\mathrm{OM}$ and generally reflects the proportion of aquatic (macrophytes and phytoplankton) vs. terrestrial plants, with higher values indicating prevailing allochthon (terrestrial) input for the OM (Meyers and Ishiwatari, 1995), i.e. enhanced development of vegetation in the lake catchment. However, some sections in the core indicate TOC / TN ratios as low as $\sim 2$ (Fig. 5). As this is too low for natural substances, selective decomposition of OM could have taken place and may have affected the TOC / TN ratio. In addition, very low amounts of TOC or TN, which are close to the detection limits, may have biased the TOC / TN ratio. TS is related to variations in $\mathrm{OM}$ production and in redox conditions within the lake. In our record, the high positive correlation between TS and TOC $(r=0.70)$ and their similar patterns suggest that higher $\mathrm{S}$ values are related to the development of anoxic conditions at the bottom of the lake due to increasing productivity and/or lake stratification.

Based on their paleoclimatic/paleoenvironmental significance, the consistent variations in all of the presented proxies (Fig. 5) perfectly match the timescale proposed by the preliminary tephrochronological framework (Fig. 4). Indeed, lower precipitation (higher $\delta^{18} \mathrm{O}_{\mathrm{TIC}}$ ), reduced lake productivity (lower TIC, TOC, and TS), contraction of terrestrial vegetation (lower TOC / TN ratio), and increase in catchment erosion (higher Ti) correspond to the colder glacial conditions of the MIS 6 and MIS 4-2 (Fig. 5). During the glacial part of the MIS 5 and the interglacial MIS 5.5 and MIS 1, warmer and wetter climate conditions, promoting primary productivity and vegetation development, are instead apparent. Interestingly, although the temporal resolution of the proxy obtained from the core catcher $\left(\delta^{18} \mathrm{O}\right.$, TIC, TOC, TOC / CN, and TS) is very low $(\sim 2 \mathrm{ka}$, based on the preliminary estimation of the sedimentation rate of ca. $0.45 \mathrm{~mm} \mathrm{a}^{-1}$ ) the interstadial/stadial pattern during the MIS 5 is also recorded by con- 
current variations in all the investigated proxies (Fig. 5). This notion is corroborated also by the similarities of the Fucino record with the high-resolution oxygen isotope time series from the Sulmona Basin (Regattieri et al., 2015, Fig. 4). Indeed, although the two series are correlated only by means of the preliminary tephrostratigraphic analyses (Fig. 4), across the four presumably common tephras, the $\mathrm{F} 1-3 \delta^{18} \mathrm{O}_{\mathrm{TIC}}$ profile seems to show the same pronounced millennial-scale fluctuations documented in the Sulmona record (Fig. 4).

\section{Conclusions}

The first multiproxy analyses performed on the newly acquired $82 \mathrm{~m}$ long core from Fucino lake sediments, along with the reinterpretation of the previous data, suggest that

i. the entire lacustrine succession in the Fucino Basin extends continuously at least up to $\sim 540 \mathrm{ka}$ and, by extrapolating the sedimentation rate $\left(0.4-0.5 \mathrm{~mm} \mathrm{a}^{-1}\right)$ to the maximum depth of ca. $900 \mathrm{~m}$, possibly 2 Ma back ;

ii. the Fucino sediments include several tephra layers from the surrounding peri-Tyrrhenian volcanic centres, most of which are suitable for both indirect (geochemical fingerprinting) and direct $\left({ }^{40} \mathrm{Ar} /{ }^{39} \mathrm{Ar}\right)$ dating;

iii. the geochemical and biogeochemical properties alongside the pollen record suggest a high sensitivity of the Fucino lacustrine sediments to the climatic and environmental changes.

In order to explore the full potential of the Fucino succession, further investigations, including detailed tephra analyses, ${ }^{14} \mathrm{C}$ and ${ }^{40} \mathrm{Ar} /{ }^{39} \mathrm{Ar}$ geochronology, and high-resolution biogeochemical, stable isotope, paleontological, and paleomagnetic analyses are in progress. Nevertheless, the present preliminary results make the Fucino Basin a good candidate for a deep-drilling project, which could provide one of the longest continuous records for studying, at both orbital and millennial scale, the Quaternary paleoclimatic history of the central Mediterranean area, possibly 2 Ma back.

Acknowledgements. We thank Michele and Valentino Pietrantoni for having kindly hosted us and for having permitted to perform the drilling in their farm. Alison Pereira is thanked for field help during the drilling. Alex Francke and Niklas Leicher provided valuable help during core management at the University of Koln.

Edited by: U. Harms

Reviewed by: J. Brigham-Grette and one anonymous referee

\section{References}

Cavinato, G. P., Carusi, C., Dall'Asta, M., Miccadei, E., and Piacentini, T.: Sedimentary and tectonic evolution of Plio-Pleistocene alluvial and lacustrine deposits of Fucino Basin (central Italy), Sediment. Geol., 148, 29-59, 2002.

D’Agostino, N., Jackson, J. A., Dramis, F., and Funiciello, R.: Interactions between mantle upwelling, drainage evolution and active normal faulting: an example from the central Apennines (Italy), Geophys. J. Int., 147, 475-497, 2001.

EPICA community members: One-to-one coupling of glacial climate variability in Greenland and Antarctica, Nature, 444, 195198, 2006.

Follieri, M., Magri, D., and Sadori, L.: Late Pleistocene Zelkova extinction in central Italy, New Phytol., 103, 269-273, 1986.

Follieri, M., Magri, D., Sadori, L., and Villa, I. M.: Palinologia e datazione radiometrica 39Ar/40 Ar di un sondaggio nella piana del Fucino (Abruzzo), Workshop evoluzione dei bacini neogenici e loro rapporti con il magmatismo Plio-Quaternario nell'area tosco-laziale, Pisa, 12-13 June 1991, 90-92, 1991.

Galadini, F. and Galli, P.: Active tectonics in the central Apennines (Italy) - input data for seismic hazard assessment, Nat. Hazards, 22, 225-270, 2000.

Galadini, F. and Galli, P.: Archaeoseismology in Italy: case studies and implications on long-term seismicity, J. Earthquake Eng., 5, 35-68, 2001.

Galli, P., Messina, P., Giaccio, B., Peronace, E., and Quadrio, B.: Early Pleistocene to Late Holocene activity of the Magnola Fault (Fucino Fault System, central Italy), B. Geofis. Teor. Appl., 53, 435-458, 2012.

Giaccio, B., Sposato, A., Gaeta, M., Marra, F., Palladino, D. M., Taddeucci, J., Barbieri, M., Messina, P., and Rolfo, M. F.: Middistal occurrences of the Albano Maar pyroclastic deposits and their relevance for reassessing the eruptive scenarios of the most recent activity at the Colli Albani Volcanic District, Central Italy, Quaternary Int., 171-172, 160-178, 2007.

Giaccio, B., Marra, F., Hajdas, I., Karner, D. B., Renne, P. R., and Sposato, A.: 40Ar/39Ar and 14C geochronology of the Albano maar deposits: Implications for defining the age and eruptive style of the most recent explosive activity at Colli Albani Volcanic District, Central Italy, J. Volcanol. Geoth. Res., 185, 203213, 2009.

Giaccio, B., Nomade, S., Wulf, S., Isaia, R., Sottili, G., Cavuoto, G., Galli, P., Messina, P., Sposato, A., Sulpizio, R., and Zanchetta, G.: The late MIS 5 Mediterranean tephra markers: A reappraisal from peninsular Italy terrestrial records, Quaternary Sci. Rev., 56, 31-45, 2012.

Giaccio, B., Regattieri, E., Zanchetta, G., Nomade, S., Renne, P. R., Sprain, C. J., Drysdale, R. N., Tzedakis, P. C., Messina, P., Scardia, G., Sposato, A., and Bassinot, F.: Duration and dynamics of the best orbital analogue to the present interglacial, Geology, 43, 603-606, 2015.

Gierlowsky-Kordesch, E. H.: Lacustrine carbonates, in: Developments in Sedimentology 61, 2-50, 2010.

Giraudi, C. and Giaccio, B.: The Middle Pleistocene glaciations on the Apennnines (Italy): New chronologcial data and considerations about the preservation of the glacial deposits, Geological Society, London, Special Publications, 433, doi:10.1144/SP433.1, in press, 2015. 
Leng, M. J., Wagner, B., Boehm, A., Panagiotopoulos, K., Vane, C. H., Snelling, A., Haidon, C.; Woodley, E., Voegel, H., Zanchetta, G., and Baneschi, I.: Understanding past climatic and hydrological variability in the Mediterranean from Lake Prespa sediment isotope and geochemical record over the Last Glacial cycle, Quaternary Sci. Rev., 66, 123-136, 2013.

Lisiecki, L. E. and Raymo, M. E.: A Pliocene-Pleistocene stack of 57 globally distributed benthic $\mathrm{d} 18 \mathrm{O}$ records, Paleoceanography, 20, PA1003, doi:10.1029/2004PA001071, 2005.

Litt, T. and Anselmetti, F. S.: Lake Van deep drilling project PALEOVAN, Quaternary Sci. Rev., 104, 1-7, 2014.

Meyers, P. A. and Ishiwatari, R.: Organic matter accumulation records in lake sediments, in: Physics and chemistry of lakes, edited by: Lerman, A., Imboden, D., and Gat, J., Springer, Berlin, 279-328, 1995.

Müller, B., Wang, Y., and Wehrli, B.: Cycling of calcite in hard water lakes of different trophic states, Limnol. Oceanogr., 51, 1678-1688, 2006.

Narcisi, B.: Caratteristiche e possibile provenienza di due livelli piroclastici nei depositi del Pleistocene superiore della Piana del Fucino (Italia centrale), Rendiconti dell'Accademia dei Lincei, Scienze Fisiche e Naturali, 5, 115-123, 1994.

Neugebauer, I., Brauer, A., Schwab, M., Waldmann, N. D., Enzel, Y., Kitagawa, H., Torfstein, A., Frank, U., Dulski, P., Agnon, A., Ariztegui, D., Ben-Avraham, Z., Goldstein, S. L., and Stein, M.: Lithology of the long sediment record recovered by the ICDP Dead Sea Deep Drilling Project (DSDDP), Quaternary Sci. Rev., 102, 149-165, 2014.

Patacca, E. and Scandone, P.: Geology of the Southern Apennines, Bollettino della Società Geologica Italiana, 7, 75-119, 2007.

Patacca, E., Scandone, P., Di Luzio, E., Cavinato, G., and Parotto, M.: Structural architecture of the central Apennines: interpretation of the CROP 11 seismic profile from the Adriatic coast to the orographic divide, Tectonics, 27, TC3006, doi:10.1029/2005TC001917, 2008.
Pross, J., Koutsodendris, A., Christanis, K., Fischer, T., Fletcher, W. J., Hardiman, M., Kalaitzidis, S., Knipping, M., Kotthoff, U., Milner, A. M., Müller, U. C., Schmiedl, G., Siavalas, G., Tzedakis, P. C., and Wulf, S.: The 1.35-Ma-long terrestrial climate archive of Tenaghi Philippon, northeastern Greece: Evolution, exploration and perspectives for future research, Newsl. Stratigr., 48, 253-276, 2015.

Regattieri, E., Giaccio, B., Zanchetta, G., Drysdale, R. N., Galli, P., Nomade, S., Peronace, E., and Wulf, S.: Hydrological variability over the Apennines during the Early Last Glacial precession minimum, as revealed by a stable isotope record from Sulmona basin, Central Italy, J. Quaternary Sci., 30, 19-31, 2015.

Roberts, N., Jones, M. D., Benkaddur, A., Eastwood, W. J., Filippi, M. L., Frogley, M. R., Lamb, H. F., Leng, M. J., Reed, J. M., Stein, M., Stevens, L., Valero-Garcès, B., and Zanchetta, G.: Stable isotope records of Late Quaternary climate and hydrology from Mediterranean lakes: the ISOMED synthesis, Quaternary Sci. Rev., 27, 2426-2441, 2008.

Vogel, H., Wagner, B., Zanchetta, G., Sulpizio, R., and Rosén, P.: A paleoclimate record with tephrochronological age control for the last glacial-interglacial cycle from Lake Ohrid, Albania and Macedonia, J. Paleolimnol., 44, 295-310, 2010.

Wagner, B., Lotter, A. F., Nowaczyk, N., Reed, J. M., Schwalb, A., Sulpizio, R., Valsecchi, V., Wessels, M., and Zanchetta, G.: A 40,000-year record of environmental change from ancient Lake Ohrid (Albania and Macedonia), J. Paleolimnol., 41, 407-430, 2009. 